\title{
Bonnaya sanpabloensis (Linderniaceae): An addition to the flora of India
}

\author{
Sardesai V.A. ${ }^{1}$, Sathe S.S. ${ }^{2}$ \& V.B. Shimpale ${ }^{1 *}$ \\ 1Department of Botany, The New College, Kolhapur - 416 012, Maharashtra, India. \\ ${ }^{2}$ Department of Botany, S. M. Dr. Bapuji Salunkhe College, Miraj - 416 410, Maharashtra, India. \\ *E-mail: vshimpale@gmail.com
}

\begin{abstract}
Bonnaya sanpabloensis (Linderniaceae) previously reported from South China, Thailand and Philippines, is newly reported for the flora of India from Maharashtra. The species is distinct from other species of the genus in having flowers in terminal racemes, pedicels almost vertical in fruiting and densely pilose staminodes.
\end{abstract}

Keywords: Bonnaya sanpabloensis, India, Linderniaceae, Maharashtra, New Record.

\section{Introduction}

The genus Bonnaya Link \& Otto was segregated from Lindernia All. by Fischer et al. (2013) on the basis of molecular and morphological evidences. The presence of a single pair of staminodes, narrow lanceolate entire or denticulate leaves, pinnate venation with clearly visible lateral veins and narrow linear capsules are the characteristic features of this genus (Bentham, 1846, 1876; Hooker, 1884; Fischer et al., 2013). During a taxonomic revision of the family Linderniaceae for the state of Maharashtra, the authors collected some interesting specimens of genus Bonnaya from the forest areas of two different districts. Laboratory studies showed a few character differences by which these specimens are distinct from all the hitherto described species from India. Therefore, the authors have approached Prof. Jenn-Che Wang, National Taiwan Normal University, Taiwan for his expert opinion and, the specimens were identified as Bonnaya sanpabloensis Y.S. Liang \& J.C. Wang, a recently described species from South China, Thailand and Philippines (Liang \& Wang, 2014). This species was previously been confused with $B$. antipoda because of its similarities

Received: 05.05.2018; Revised \& Accepted: 25.03.2019

Published Online: 30.06.2019 in morphological characters, but differs from B. antipoda by having 8-16 pairs of teeth on the leaf margins, a racemose inflorescence, densely pilose staminodes and fruiting pedicels held almost vertically. As the species is added for the first time to the flora of India, a detailed description, photo plate and notes on its distribution are presented here.

Bonnaya sanpabloensis Y.S. Liang \& J.C. Wang, Australian Systematic Botany 27: 192. 2014. Type: PHILIPPINES, Luzon, Laguna Province, San Pablo City, 23.11.2007, Y.S. Liang 1534 (holo PNH; iso TAIF, TNM, TNU)

Fig. 1

Annual, erect to ascending (sometimes creeping) herbs, 25-30 cm long (rarely upto $1 \mathrm{~m}$ ); rooting at lower nodes. Stems branched, usually quadrangular, glabrous, green to brown; internodes $2-4 \mathrm{~cm}$ long. Leaves sessile or subsessile, oblong-obovate to elliptic, $2-4 \times 0.5-1 \mathrm{~cm}$, obtuse or rarely acute at apex, acute at base, margins serrate with 7-15 pairs of teeths, glabrous on both surfaces, pinnately veined, secondary veins 9-11 pairs. Racemes lax, glabrous. Flowers $8-15$ on each peduncle, with a subtending bract; bracts linear-lanceolate, 2-4 $\mathrm{mm}$ long in flowers, $6-8 \mathrm{~mm}$ in fruiting; pedicels ascending in flowers, almost vertical in fruits, 3-20 $\mathrm{mm}$ long in flowers, $10-20 \mathrm{~mm}$ long in fruits. Calyx deeply 5-lobed; lobes linear-lanceolate, acute to acuminate, glabrous, appressed in fruiting, $3-5 \times$ c. $1 \mathrm{~mm}$ in flower, $4-6 \mathrm{~mm}$ long in fruiting. Corolla bi-lipped, 9-12 $\mathrm{mm}$ long, abaxially sparsely glandular, blue to purple, upper 2-lobed, 4-5 × 2-3 $\mathrm{mm}$, lower 3-lobed, 3-4 × 3.2-4 mm, middle lobe elongated, with a white mark at the base. Stamens 2; filaments $1.3-2.2 \mathrm{~mm}$ long, pale blue to pale purple; anther 1.2-1.6 mm long. Staminodes 2, clavate, 5-6 mm long, lower half white and pilose, upper half glabrous and yellow. Ovary cylindrical, c. $2 \mathrm{~mm}$ long, c. $0.8 \mathrm{~mm}$ wide; style 5-6 mm long; 


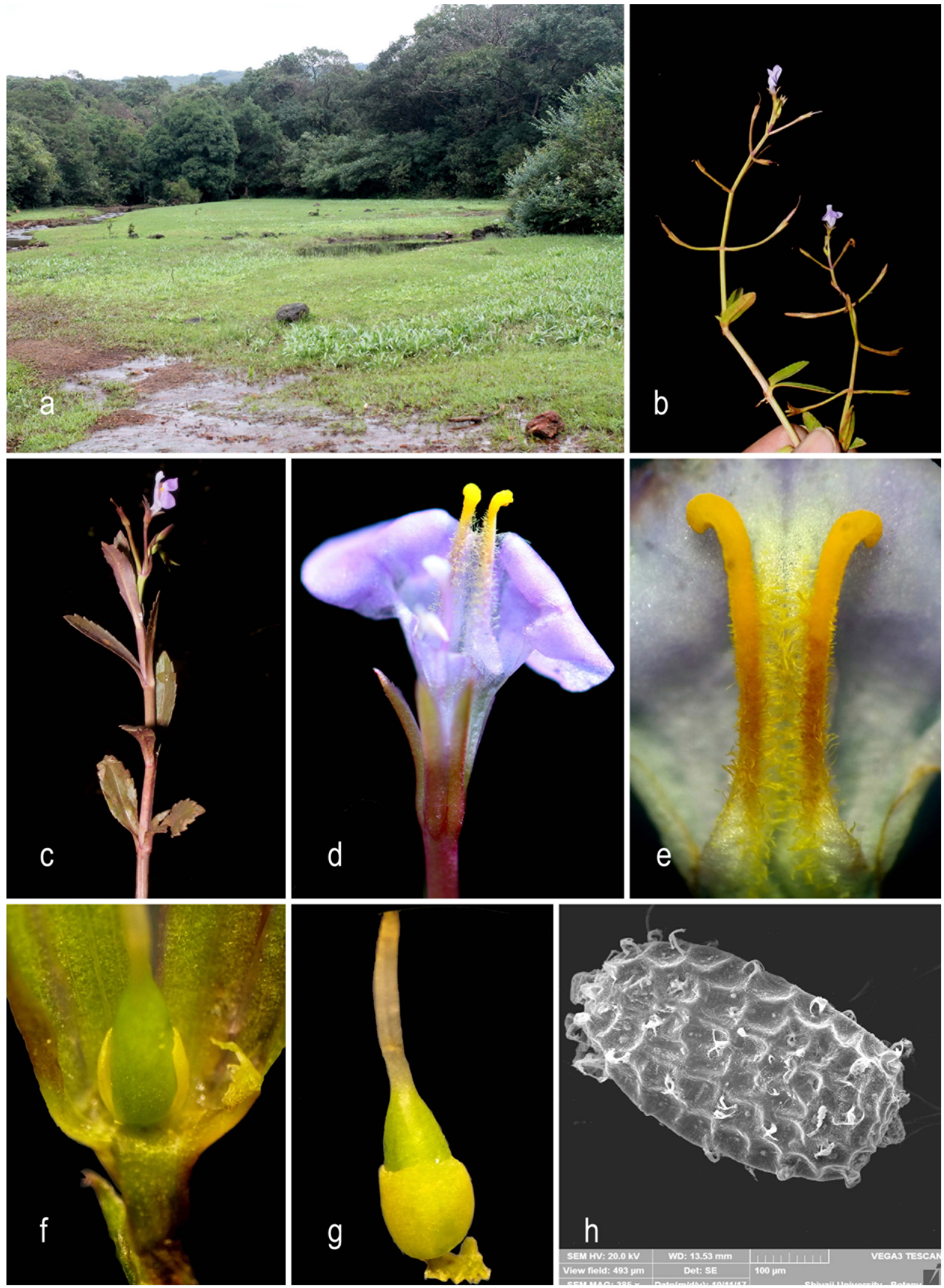

Fig. 1. Bonnaya sanpabloensis Y.S. Liang \& J.C. Wang: a. Habitat; b \& c. Flowering twig of Ajara and Amboli populations respectively; d. Single flower; e. Staminodes; f. Pistil; g. Ovary with disc; h. SEM of seed. 
disc yellow to greenish, adherent to ovary on ventral side. Capsules cylindrical, 1.3-1.8 cm long, 1-2 mm wide, acute at apex, slightly shorter than fruiting pedicels, 2-3 times longer than fruiting calyx. Seeds many, angular, brownish, 0.3-0.4 mm long, $0.2-0.3 \mathrm{~mm}$ wide, scrobiculate, with stellate projections and scattered mesh.

Flowering \& fruiting: Throughout year.

Habitat: Grows along river beds at elevation ranging from 2000 to 2260 feet.

Distribution: Known from southern China, Thailand and the Philippines (Liang \& Wang, 2014) and now from Maharashtra, India.

Specimens examined: INDIA, Maharashtra, Kolhapur district, Ajara tahshil, Ajara village, $16^{\circ} 04^{\prime} 49^{\prime \prime} \mathrm{N}$, 74²'36.8"E, 2165 ft., 29.10.2016, Sardesai \& Shimpale 2145 (The New College Herbarium, SUK!); Sindhudurg district, Sawantwadi tahshil, Amboli village $15^{\circ} 57^{\prime} 10^{\prime \prime} \mathrm{N}, 74^{\circ} 01^{\prime} 32^{\prime \prime} \mathrm{E}, 2234 \mathrm{ft}$., 12.11.2016, Sardesai \& Shimpale 2148 (The New College Herbarium, SUK!).

Notes: During the present study two different populations were noticed from similar habitats. The Amboli population showed brown coloured leaves and inflorescence with a few flowers whereas the Ajara population showed a dense inflorescence. Plants were growing associated with Bonnaya antipoda (L.) Druce, B. hyssopoides (L.) Haines, Cyperus sp., Lindernia anagalis (Burm.f.) Pennell Ludwigia sp. and Panicum sp.

According to Liang and Wang (2014) the flowers are solitary and axillary or in terminal racemes in $B$. antipoda while always in terminal racemes in $B$. sanpabloensis. But Philcox (1968) noted that, the flowers are in racemes or solitary in the leaf axils and intermediate between these two types being quite frequent in B. antipoda. Hence the character of inflorescence is overlapping and cannot be considered as a diagnostic character for segregation of the species. However, B. sanpabloensis can be separated from the morphologically similar $B$. antipoda in having clearly vertical fruiting pedicel (vs. ascending pedicel), smooth pollen exine surface ( $v$ s. rough surface) and densely pilose, 5-6 $\mathrm{mm}$ long staminodes (vs. sub-glabrous, 3.3-4.3 mm long).

\section{Acknowledgements}

Authors are thankful to Prof. Jenn-Che Wang, National Taiwan Normal University, Taiwan for confirming the identity of specimen and Principal, The New College, Kolhapur for financial assistance under the scheme 'Seed money' for research grant.

\section{Literature Cited}

BENTHAM G. 1846. Scrophulariaceae. In: CANDOLLE A.P.DE (ed.), Prodromus systematis naturalis regni vegetalis. Volume 10. Victor Masson, Paris. pp. 409-422.

BENTHAM G. 1876. Scrophulariaceae. In: BENTHAM G. \& J.D. HOOKER (eds.), Genera Plantarum. Volume 2. L. Reev. \& Co., London. pp. 954-956.

FISCHER E., SCHÄFERHOFF B. \& K. MÜLLER 2013. The phylogeny of Linderniaceae-the new genus Linderniella and new combinations within Bonnaya, Craterostigma, Lindernia, Micranthemum, Torenia and Vandellia. Willdenowia 43: 209-238.

HOOKER J.D. 1884. Flora of British India. Volume 4. L. Reev \& Co., London. p. 284

LIANG Y.S. \& J.C. WANG 2014. A systematic study of Bonnaya section Bonnaya (Linderniaceae). Australian Systematic Botany 27: 180-198.

PHILCOX D. 1968. Revision of the Malesian species of Lindernia All. (Scrophulariaceae). Kew Bulletin 22: 1-72. 